\title{
Inhibitory Action of Clozapine on Rat Ventral Tegmental Area Dopamine Neurons Following Increased Levels of Endogenous Kynurenic Acid
}

\author{
Lilly Schwieler' and Sophie Erhardt*,' \\ 'Department of Physiology and Pharmacology, Karolinska Institute, Stockholm, Sweden
}

\begin{abstract}
The mode of action by which the atypical antipsychotic drug clozapine exerts its superior efficacy to ameliorate both positive and negative symptoms is still unknown. In the present in vivo electrophysiological study, we investigate the effects of haloperidol (a typical antipsychotic drug) and clozapine on ventral tegmental area (VTA) dopamine (DA) neurons in a situation of hyperdopaminergic activity in order to mimic tentatively a condition similar to that seen in schizophrenia. Increased DA transmission was induced by elevating endogenous levels of the $N$-methyl-D-aspartate receptor and $\alpha 7$ * nicotinic receptor antagonist kynurenic acid (KYNA; by means of PNU | 5656 | A, $40 \mathrm{mg} / \mathrm{kg}$, i.v.). In control rats, i.v. administered haloperidol (0.05-0.8 mg/ $/ \mathrm{kg}$ ) or clozapine ( $1.25-10 \mathrm{mg} / \mathrm{kg})$ was associated with increased firing rate and burst firing activity of VTA DA neurons. However, in rats displaying hyperdopaminergia (induced by elevated levels of KYNA), the effects of clozapine on VTA DA neurons were converted into pure inhibitory responses, including decrease in burst firing activity. In contrast, haloperidol still produced an excitatory action on VTA DA neurons in rats with elevated levels of endogenous brain KYNA. The results of the present study suggest that clozapine facilitates or inhibits VTA DA neurotransmission, depending on brain concentration of KYNA. Such an effect of clozapine may be related to its unique effect in also ameliorating negative symptoms of schizophrenia.

Neuropsychopharmacology (2003) 28, 1770-1777, advance online publication, 16 July 2003; doi:I 0. I038/sj.npp. 1300255
\end{abstract}

Keywords: electrophysiology; haloperidol; schizophrenia; PNU I5656 IA; NMDA; bursts

\section{INTRODUCTION}

Schizophrenia has for decades been associated with dopaminergic (DA) hyperactivity (Abi-Dargham et al, 2000; see Carlsson et al, 2001). The beneficial effects of classic antipsychotic drugs (eg haloperidol), especially with regard to ameliorating the positive symptoms of schizophrenia, are thought to be related to a reduced DA neurotransmission within the limbic region of the brain (see Carlsson et al, 2001 ), in particular, to antagonism of DA- $\mathrm{D}_{2}$ receptors. A profound blockade of $\mathrm{DA}-\mathrm{D}_{2}$ receptors in the basal ganglia is, however, also associated with side effects, such as extrapyramidal symptoms (EPS; Farde et al, 1992; see Gerlach, 2002). The antipsychotic drug clozapine, with remarkable efficacy in treatment-resistant schizophrenia, has very low incidence of EPS and has thus been classified as an atypical antipsychotic drug (Claghorn et al, 1987; Coward

*Correspondence: Dr S Erhardt, Department of Physiology and Pharmacology, Karolinska Institute, SE 17I 77 Stockholm, Sweden, Tel: + 46872867 06, Fax: + 4683106 22,

E-mail: Sophie.Erhardt@fyfa.ki.se

Received 25 February 2003; revised 16 May 2003; accepted 20 May 2003

Online publication: 27 May 2003 at http://www.acnp.org/citations/ Npp05270308I/default.pdf et al, 1989). Another beneficial effect of clozapine is its superior efficacy in also ameliorating negative symptoms. During the last decade, large efforts have been made to understand the mode of antipsychotic action of clozapine, but despite a large number of studies, our knowledge remains fragmentary. It is established that clozapine not only interacts with all DA receptors (the $\mathrm{D}_{4}$ subtype showing the highest affinity (19 nM; Van Tol et al, 1991)), but also with other metabotropic receptors, for example, those for serotonin $\left(5 \mathrm{HT}_{1}\right.$ and $5 \mathrm{HT}_{2}$; Canton et al, 1990), acetylcholine (Snyder et al, 1974), noradrenaline (see Coward, 1992), and histamine (see Brunello et al, 1995; see Coward, 1992). Previous studies also point to an interaction with some ionotropic receptors, for example, the $N$-methyl-D-aspartate (NMDA) receptor (Arvanov et al, 1997; Ossowska et al, 1999 ) and the $\mathrm{GABA}_{\mathrm{A}}$ receptor (Squires and Saederup, 1998). It has been suggested that clozapine has a preferential action on the mesolimbic DA system as compared to the nigrostriatal DA system (Andén and Stock, 1973; Bartholini, 1976; Chiodo and Bunney, 1983, 1985; Moghaddam and Bunney, 1990). Moreover, since clozapine is a potent serotonin $5-\mathrm{HT}_{2}$-receptor antagonist, it has been suggested that concurrent $5-\mathrm{HT}_{2}$ and $\mathrm{DA}-\mathrm{D}_{2}$ receptor antagonism may contribute to its atypical profile (see Deutch et al, 1991; Ichikawa et al, 2001; Meltzer and Nash, 1991). 
Previous electrophysiological studies show that all antipsychotic drugs, including clozapine and haloperidol, when acutely administered increase the firing rate and burst firing activity of ventral tegmental area (VTA) DA neurons (Gessa et al, 2000; Tung et al, 1991; White and Wang, 1983). However, most of these results derive from studies where naive control rats have been used. In the present in vivo electrophysiological study, we investigate the effects on VTA DA neurons of clozapine or haloperidol in a situation of hyperdopaminergia in order to mimic tentatively a condition similar to that occurring in schizophrenia. Increased DA transmission was pharmacologically induced by administration of the kynurenine 3-hydroxylase inhibitor PNU 156561A, thereby elevating endogenous brain levels of the NMDA-receptor antagonist kynurenic acid (KYNA). Previous studies demonstrate that such treatment is associated with increased firing rate and burst firing activity of rat midbrain DA neurons (Erhardt and Engberg, 2002; Erhardt et al, 2001a).

\section{MATERIALS AND METHODS}

\section{Animals}

Experiments were performed on male Sprague-Dawley rats (B\&K Universal AB, Sollentuna, Sweden; weighing between 200 and $250 \mathrm{~g}$ ). The animals were housed in groups of five, and free access to food and water was provided. Environmental conditions were checked daily and maintained under constant temperature $\left(25^{\circ} \mathrm{C}\right)$ and $40-60 \%$ humidity in a room with a regulated 12 -h light/dark cycle (lights on at 0600). Experiments were approved by and performed in accordance with the guidelines of the Ethical Committee of Northern Stockholm, Sweden and all efforts were made to minimize the number of animals used and their suffering.

\section{Surgery}

Before surgery, rats were pretreated with PNU 156561A (dissolved in $10 \% \beta$-cyclodextrin) or vehicle i.v. The animals were placed in a restrainer and a temporary cannula was inserted into a lateral tail vein. Following drug administration, the cannula was removed and the rats were placed individually in a Plexiglas cage. About $5 \mathrm{~h}$ later, rats were anesthetized (chloral hydrate; $400 \mathrm{mg} / \mathrm{kg}$, intraperitoneally) and then mounted onto the ear bars of a conventional stereotaxic frame (David Kopf Instruments, Tujunga, CA, USA) so that the skull was set in a horizontal plane and the nose was secured using a clamp at the front of the frame. For i.v. administration, a cannula was again inserted into a lateral tail vein and additional injections of chloral hydrate were given as they were required to maintain a stable level of anesthesia. Also, clozapine and haloperidol were given through the lateral tail vein. Throughout the experiments, the body temperature of the animals was maintained at $37^{\circ} \mathrm{C}$ by means of a thermostatic heating pad. The skull surface was exposed and a 3-mm burr hole was drilled with its center located approximately $3 \mathrm{~mm}$ anterior to the lambda and $0.7 \mathrm{~mm}$ lateral to the midline.

\section{Extracellular Single Unit Recording}

Following careful removal of the dura, a glass microelectrode with a tip diameter of approximately $1-2 \mu \mathrm{m}$ (filled with $2 \mathrm{M}$ sodium acetate saturated with Pontamine Sky Blue) was lowered by means of a hydraulic microdrive (David Kopf Instruments, Tujunga, CA, USA) into the region of VTA, according to the stereotaxic coordinates from the atlas of Paxinos and Watson (1998). The in vitro impedance of the electrode was generally $5-8 \mathrm{M} \Omega$, measured at $135 \mathrm{~Hz}$ in $0.9 \%$ saline. Single unit potentials were passed through a high input-impedance amplifier and filters. The impulses were discriminated from background noise and fed into a computer, and simultaneously displayed on a digital storage oscilloscope, monitored on an audio monitor and on a strip chart recorder (Gould). All DA neurons were found $7.5-8.5 \mathrm{~mm}$ from the brain surface and all DA neurons fulfilled the neurophysiological characteristics (triphasic action potential of more than $2.0 \mathrm{~ms}$, basal firing rates of 1 and $10 \mathrm{~Hz}$, and frequent occurrence of burst firing) previously described for DA neurons in the VTA (Wang, 1981). Only one DA neuron was studied in each rat. The position of the electrode was marked at the end of each experiment by iontophoretic ejection of Pontamine Sky Blue. The brains were subjected to conventional histological procedures for verification of recording sites. All recording sites were found within the boundaries of the VTA. Anatomical subdivisions (nucleus parabrachialis pigmentosus (PBP) or nucleus paranigralis (PN)) were assessed according to the atlas of Paxinos and Watson (1998).

\section{Data Analysis}

The distribution of spikes was analyzed online utilizing a Macintosh computer. The software used for the analysis of firing was written in-house using a high-level objectoriented programming language called ' $G$ ' (Lab VIEW; National Instruments, Austin, TX, USA). The software was designed to sample and analyze the intervals of an arbitrary number of TTL pulses (corresponding to spikes passing through the discriminating filter) using a time resolution of $1 \mathrm{~ms}$. An interspike interval was designated as the time (in $\mathrm{ms}$ ) elapsed between the rising edges of two sequential TTL pulses. In order to avoid artifacts in the sampling procedure, the spike analyzer ignored time intervals below $20 \mathrm{~ms}$. The onset of a burst was determined as an interspike interval shorter than $80 \mathrm{~ms}$ and the termination of a burst by the next interval longer than $160 \mathrm{~ms}$ (Grace and Bunney, 1984a, b). The software program also sorted the intervals of recorded spikes and divided them into $3 \mathrm{~ms}$ bins and displayed the results as an interspike time interval histogram (ISH) with regard to the number of intervals corresponding to each bin. The intervals were analyzed with regard to the number of bursts that occurred during a 100spike sampling period along with the calculation of the percentage of spikes fired in bursts. Firing rate, percentage of spikes fired in bursts and variation coefficient (calculated as the ratio between the standard deviation and the mean interval of an ISH and used as a measure of the regularity of firing; Werner and Mountcastle, 1963), were expressed as the median of at least three consecutive ISHs. 


\section{Drugs}

The following drugs were used: chloral hydrate (Merck, Darmstadt, Germany), PNU 156561 A [ $R, S)$-2-amino-4-oxo4(3'-f'-dichlorophenyl) butanoic acid] (kindly donated by Dr C Speciale, Pharmacia \& Upjohn, Milano, Italy), $\beta$ cyclodextrin, clozapine (Sigma, St Louis, MO, USA), and haloperidol (Janssen Pharmaceutical, NV, 2340 Beerse, Belgium).

\section{Statistical Analysis}

Statistically significant differences regarding firing rate, burst firing activity, and variation coefficient were established using the Kruskal-Wallis analysis of variance followed by the Wilcoxon signed rank test or the MannWhitney $U$-test. Significance was assumed for all values where $P<0.05$.

\section{RESULTS}

I.V. administration of the atypical antipsychotic drug clozapine $(n=11 ; 1.25-10 \mathrm{mg} / \mathrm{kg})$ or the classic antipsychotic drug haloperidol $(n=7 ; 0.05-0.8 \mathrm{mg} / \mathrm{kg})$ produced a dose-dependent increase in firing rate and in the percentage of spikes fired in bursts of VTA DA neurons (Table 1, Figure 1). No significant effects on the regularity of firing, expressed as the variation coefficient, were observed by either drug (Figures 3 and 4). Clozapine or haloperidol produced a significant increase in the mean number of bursts (recorded during a 100-spike sampling period) as well as in the mean number of spikes per bursts when compared with predrug levels (see Table 1). Moreover, two of nine DA neurons were excluded from analysis due to induction of depolarization block after 0.2 and $0.4 \mathrm{mg} / \mathrm{kg}$ haloperidol, respectively.

Administration of PNU 156561A ( $40 \mathrm{mg} / \mathrm{kg}$, i.v., $5-7 \mathrm{~h}$ ) has previously been shown to elevate endogenous levels of KYNA three- to five-fold (Erhardt and Engberg, 2000, 2002; Erhardt et al, 2000, 2001a, b, 2002a) and to increase significantly firing rate and percent spikes fired in bursts of rat midbrain DA neurons (Erhardt and Engberg, 2002; Erhardt et al, 2001a). However, in the present study efforts were made to avoid recording of DA neurons with very high frequency and burst firing activity, that is, basal firing rate over $10 \mathrm{~Hz}$ and basal percentage of spikes fired in bursts over $90 \%$. In line with our previous study (Erhardt and Engberg, 2002), 25\% of all VTA DA neurons in rats with elevated levels of KYNA occasionally showed depolarization-block characteristics. Such neurons were excluded from pharmacological analyses. In spite of these limitations, a tendency toward higher basal frequency and higher basal percentage of spikes fired in bursts were found in rats with elevated KYNA levels (Figures 2, 3a,b), although no statistical significances were obtained due to the relatively low numbers of neurons analyzed.

Pretreatment with PNU $156561 \mathrm{~A}(40 \mathrm{mg} / \mathrm{kg}$, i.v., $n=8,5-$ $7 \mathrm{~h}$ ) was found not only to antagonize the increase in firing rate and percentage of spikes fired in burst of VTA DA neurons induced by clozapine $(1.25-10 \mathrm{mg} / \mathrm{kg}$, i.v.), but also to reverse the action of clozapine, leading to a tendency in reduction in firing rate and to a significant decrease in the
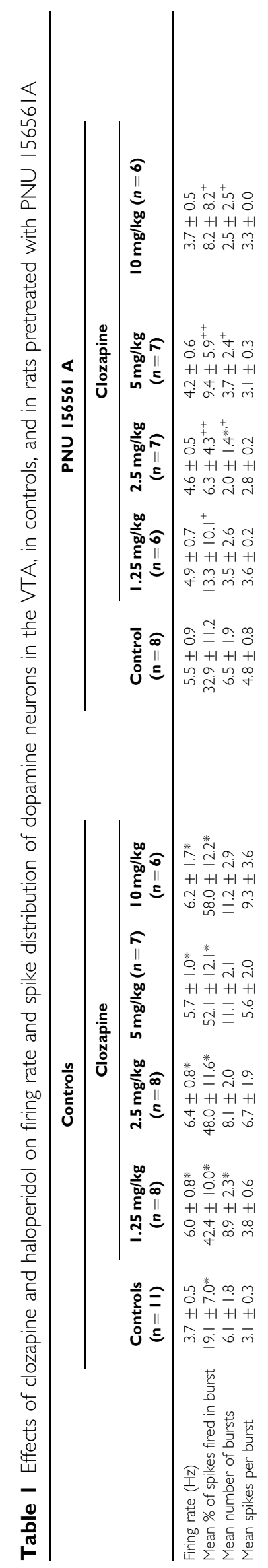

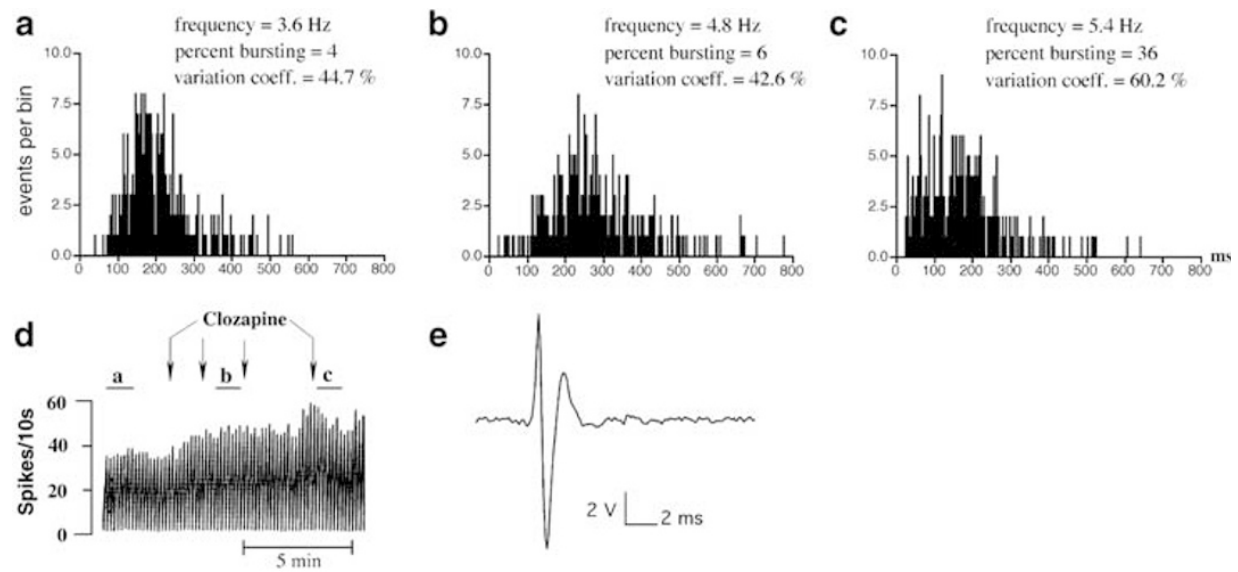

Figure I Extracellular recording from a spontaneously bursting DA neuron in the VTA depicting the effect of i.v. administration of clozapine. (a) ISH before drug administration. (b) ISH after administration of clozapine $(2.5 \mathrm{mg} / \mathrm{kg}$, i.v.). (c) ISH after administration of clozapine (I0 mg/ $/ \mathrm{kg}$, i.v.). (d) Cumulative rate histogram showing the action of clozapine $(1.25+1.25+2.5+5 \mathrm{mg} / \mathrm{kg}$, injected at arrows) on the firing rate. Horizontal bars indicate the time periods where the three ISHs were recorded. (e) Spontaneous action potential from the same DA neuron.
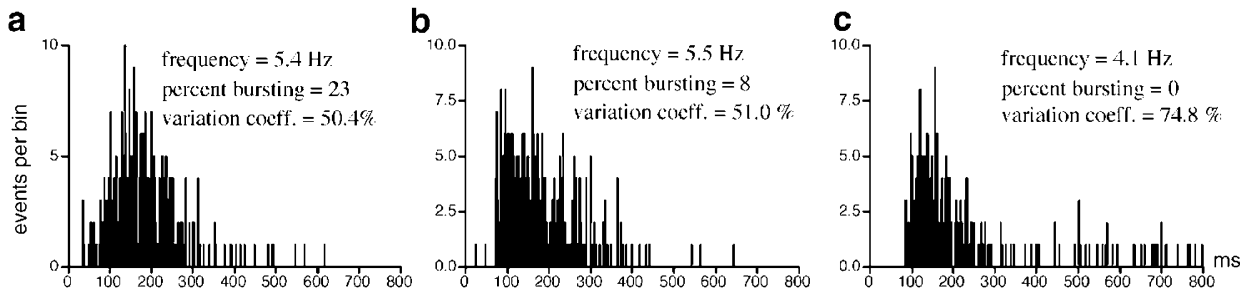

d

e
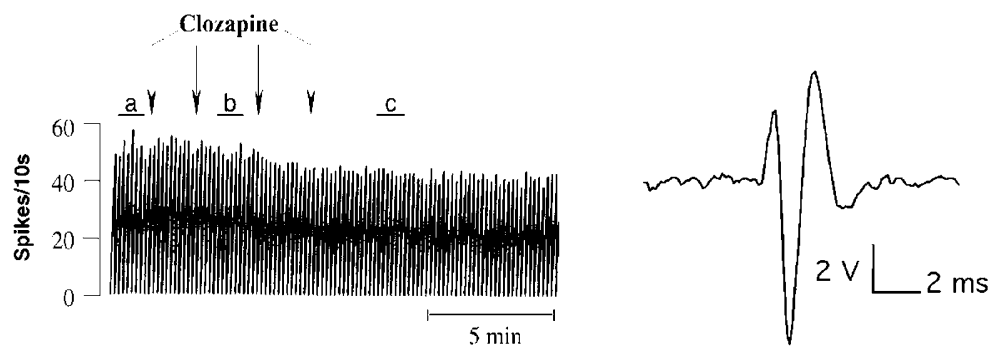

Figure 2 Extracellular recording from a spontaneously bursting DA neuron in the VTA depicting the effect of i.v. administration of clozapine following pretreatment with PNU I5656I A (40 mg/kg, i.v., 6 h). (a) ISH before drug administration. (b) ISH after administration of clozapine (2.5 mg/kg, i.v.). (c) ISH after administration of clozapine ( $10 \mathrm{mg} / \mathrm{kg}$ i.v). (d) Cumulative rate histogram showing the action of clozapine $(1.25+1.25+2.5+5 \mathrm{mg} / \mathrm{kg}$, injected at arrows) on the firing rate. Horizontal bars indicate the time periods where the three ISHs were recorded. (e) Spontaneous action potential from the same DA neuron.

percentage of spikes fired in burst (Table 1, Figure 2). This reduction in burst firing activity was observed in seven of eight DA neurons, irrespective of predrug basal characteristics. Furthermore, four of seven spontaneously bursting neurons were converted into nonbursting neurons by clozapine. Thus, this pretreatment decreased the average number of burst during a 300-spike sampling period as well as the number of spikes within a burst (see Table 1). No significant effects on the regularity of firing expressed as the variation coefficient was observed (Figures 3).

In contrast to clozapine, the effects of haloperidol (see Figures 4) on VTA DA neurons after pretreatment with PNU 156561 A seemed to be clearly potentiated, since haloperidol forced all DA neurons recorded into depolarization block already after $0.1 \mathrm{mg} / \mathrm{kg}$ haloperidol (see Table 1 ).

\section{DISCUSSION}

The present study describes an interaction between endogenous KYNA and the response of VTA DA neurons to various antipsychotic drugs. KYNA is a noncompetitive antagonist of the NMDA receptor ion-channel complex, acting on the strychnine-insensitive glycine recognition site (Birch et al, 1988), with an $\mathrm{IC}_{50}$ in the low micromolar range $\left(\mathrm{IC}_{50}=7.9 \mu \mathrm{M}\right.$; Ganong and Cotman, 1986; Kessler et al, 1989; Parsons et al, 1997). Furthermore, a recent study showed that KYNA blocks the $\alpha 7^{\star}$ nicotinic receptor with the same $\mathrm{IC}_{50}$ value as for the glycine-site of the NMDA receptors (Hilmas et al, 2001).

Previous studies have shown that the concentration of KYNA is elevated in the cerebrospinal fluid of schizophrenic patients (Erhardt et al, 2001c) as well as in the post- 


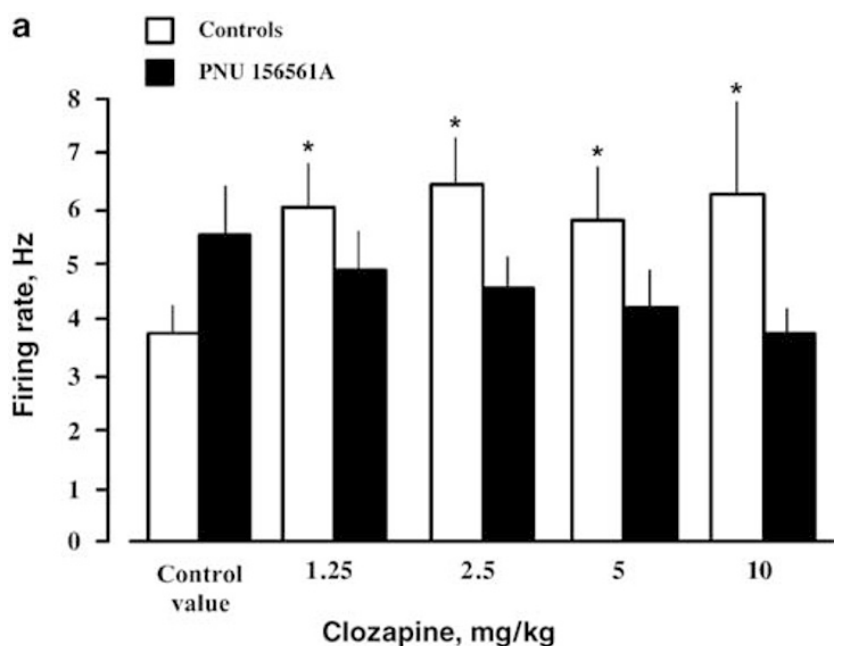

b
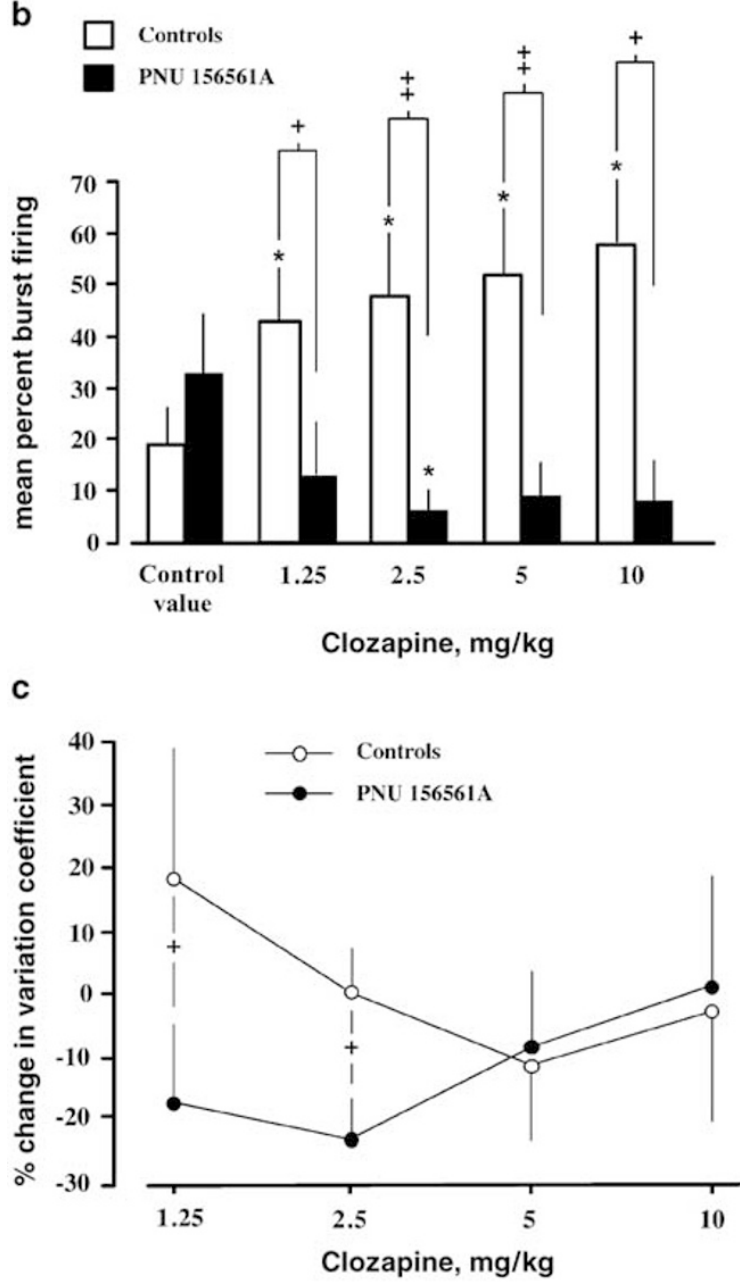

Figure 3 Effects of incremental doses of i.v. administered clozapine $(1.25-10 \mathrm{mg} / \mathrm{kg})$ in control rats and rats pretreated with PNU I5656 | A ( $40 \mathrm{mg} / \mathrm{kg}$, i.v., $5-7 \mathrm{~h}$ ) on (a) the firing rate, (b) the percent burst firing activity and (c) the regularity of firing (assessed by the variation coefficient). Each value represents mean \pm SEM from six to II VTA DA neurons. Statistic: $* P<0.05$ (Wilcoxon signed rank test) vs corresponding predrug value and ${ }^{+} P<0.05,{ }^{+}+P<0.01$ vs corresponding control value (the Mann-Whitney U-test).
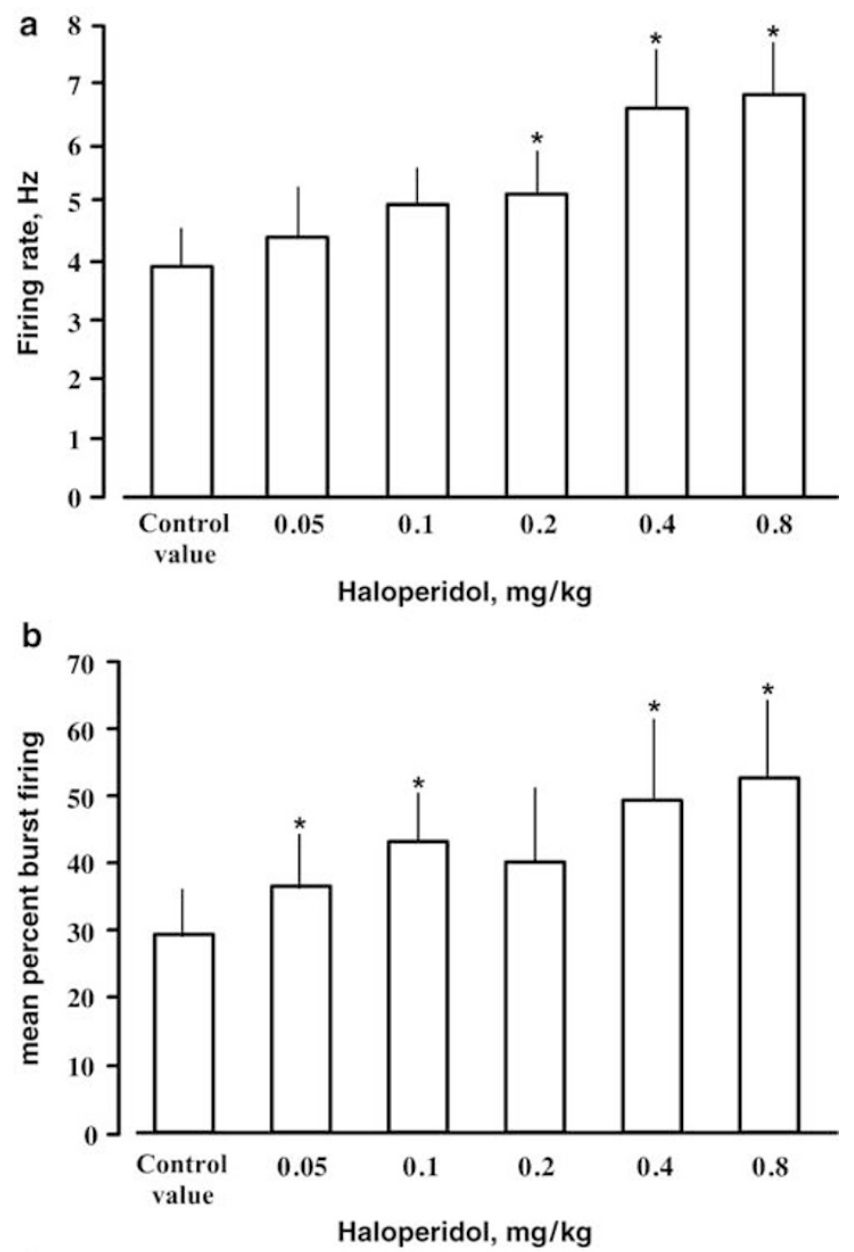

C

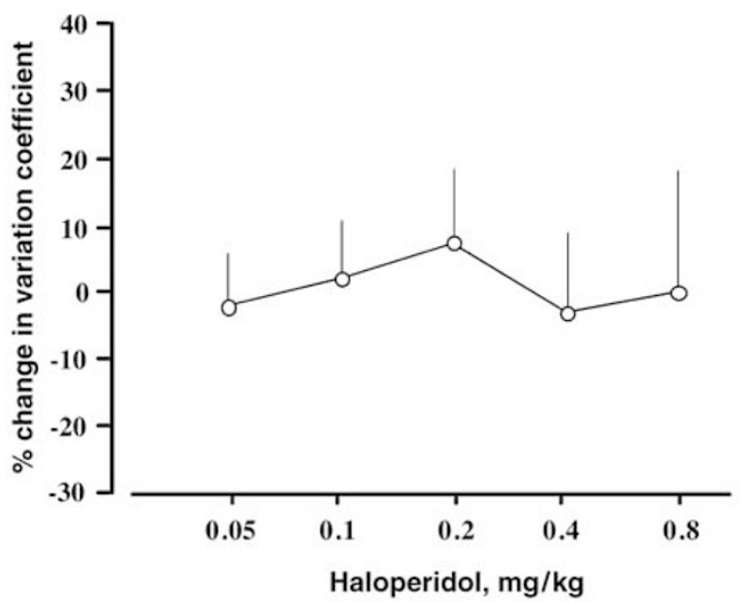

Figure 4 Effects of incremental doses of i.v. administered haloperidol $(0.05-0.8 \mathrm{mg} / \mathrm{kg})$ in control rats on (a) the firing rate, (b) the percent burst firing activity, and (c) the regularity of firing (assessed by the variation coefficient). Each value represents mean \pm SEM from six to seven VTA DA neurons. Statistic: $* P<0.05$ (the Wilcoxon signed rank test) vs corresponding predrug value.

mortem brain of schizophrenics (Schwarcz et al, 2001). Interestingly, a three- to five-fold increase in endogenous levels of rat brain KYNA is associated with dramatic effects on neuronal firing of midbrain DA neurons, including 
increased firing rate and burst firing activity (Erhardt and Engberg, 2002; Erhardt et al, 2001a).

The results of the present study show that i.v. administration of clozapine or haloperidol increases the firing rate and burst firing activity of VTA DA neurons. These findings are in excellent agreement with previous in vivo electrophysiological studies (Gessa et al, 2000; Tung et al, 1991; White and Wang, 1983) and it is generally accepted that antipsychotic drugs increase DA cell firing rate by blockade of somatodendritic DA autoreceptors (Pucak and Grace, 1994, 1996). However, in a situation of hyperdopaminergia induced by elevation of brain KYNA (Erhardt and Engberg, 2000, 2002; Erhardt et al, 2000, 2001a, b, 2002a; Speciale et al, 1996), the excitatory effects of clozapine observed in control rats were converted into pure inhibitory responses by the drug. In contrast, the excitatory action of haloperidol on VTA DA neurons was even more pronounced in rats with elevated levels of endogenous brain KYNA, since administration of the drug in low doses was associated with a depolarization block of all DA neurons recorded. This finding is in sharp contrast with a previous electrophysiological study showing that i.c.v. administration of KYNA blocks the excitatory action of systemically administered haloperidol on VTA DA neurons (Tung et al, 1991). The discrepancy between these results may be related to different routes of elevating KYNA levels in the brain (Erhardt and Engberg, 2000).

The potentiated effect of haloperidol and the conversion of clozapine's effects into an inhibitory response seen in rats with elevated brain levels of KYNA were unexpected and point to a profound difference in the mode of action between these drugs. Judging from previous electrophysiological studies, a decreased glutamatergic tone in the brain is associated with an increase of neuronal activity of midbrain DA neurons. Thus, systemic administration of NMDA-receptor antagonists, for example, MK 801, phencyclidine and ketamine as well as elevated KYNA levels in brain are associated with an increased neuronal activity of these neurons (Erhardt and Engberg, 2002; Erhardt et al, 2001a; French, 1994; French et al, 1993; Murase et al, 1993). These paradoxical effects of glutamate receptor antagonists are thought to be induced by an inadequate balance of afferent regulation by GABAergic and glutamatergic projections, for example, from the prefrontal cortex and/or subcortical areas (Carr and Sesack, 2000; Kalivas et al, 1993; Phillipson, 1979; Sesack et al, 1989). In particular, it is suggested that KYNA primarily reduces the activity of GABAergic projections to the VTA, thereby activating VTA DA neurons by a decreased GABAergic tone (Erhardt and Engberg, 2002; Erhardt et al, 2002b). With regard to haloperidol, an inadequate balance between GABAergic and glutamatergic afferents, as induced by elevated KYNA levels, may promote the drug to induce depolarization block by its potent antagonism at somatodendritic $\mathrm{DA}-\mathrm{D}_{2}$ receptors.

The excitatory and inhibitory effects of i.v. administered clozapine on VTA DA neurons in control rats and in rats with elevated levels of KYNA, respectively, show striking similarities with the effects of i.v. administered nicotine on these neurons (Erhardt et al, 2002a). However, the effects of nicotine on VTA DA neurons were suggested to be the result of an interaction with glutamatergic mechanisms and unrelated to an activation of $\alpha 7^{\star}$ nicotinic receptors, since addition of the glycine-site agonist D-cycloserine to PNU $156561 \mathrm{~A}$ pretreated rats restored the excitatory action of nicotine (Erhardt et al, 2002a). Judging from the present results, the inhibitory action of clozapine in rats with elevated brain levels of KYNA appears to be dissociated from an effect on DA receptors, and rather related to interference with glutamatergic or cholinergic mechanisms. Present data do not allow any definitive conclusion regarding the mechanism behind the inhibitory action of clozapine on VTA DA neurons. Hypothetically, the effect could be mediated by (I) activation of presynaptic $\alpha 7^{*}$ nicotinic receptors located on glutamatergic afferents (McGehee et al, 1995; Wonnacott et al, 2000; leading to a potentially increased glutamate release by clozapine) (II) activation of postsynaptic $\alpha 7^{\star}$ nicotinic receptor, located on cell soma or dendrites of VTA DA neurons or (III) displacement of KYNA at postsynaptic NMDA receptors located on cell soma or dendrites of GABAergic neurons projecting to VTA DA neurons, thereby restoring the balance between GABAergic and glutamatergic projections to the VTA. An interaction between clozapine and the $\alpha 7^{*}$ nicotinic receptor is supported by the demonstration of a clozapine-induced release of acetylcholine in the prefrontal cortex (Ichikawa et al, 2002). In favor of an interaction by clozapine with glutamatergic mechanisms, treatment augmentation studies with agents acting at the glycine-site of the NMDA receptor have shown that glycine and Dcycloserine improve negative symptoms when added to conventional antipsychotic drugs, but not when added to clozapine (Evins et al, 2002; Goff et al, 1999, Heresco-Levy et al, 1998, 1999; Javitt et al, 1994; Tsai et al, 1998). This indicates that clozapine may be an agonist or partial agonist at the glycine-site of the NMDA receptor or an inhibitor of the glycine transporter and such actions may contribute to its unique clinical efficacy. Interestingly, judging from the results of the present study, clozapine resembles the effect of D-cycloserine on VTA DA neurons, that is, an excitatory action in control rats and an inhibitory effect in rats with elevated levels of KYNA (Erhardt and Engberg, 2002). Preliminary data from our laboratory also point to an interaction of clozapine with the glycine transporter (unpublished data).

In conclusion, the present study demonstrates profound differences between haloperidol and clozapine with regard to their effects on the neuronal activity of VTA DA neurons as revealed by elevation of endogenous brain KYNA levels. Thus, in a situation of hyperdopaminergia, the excitatory action of haloperidol is potentiated, whereas clozapine facilitates or inhibits VTA DA neurotransmission, depending on the pre-existent DA tone. Tentatively, these actions of clozapine and haloperidol may also contribute to differences in clinical efficacy between these drugs.

\section{ACKNOWLEDGEMENTS}

This study was supported by the Swedish Medical Research Council (No. 7484), Åhlén-stiftelsen, Stiftelsen, Fredrik och Ingrid Thurings stiftelse, Syskonen Svenssons Fond för Medicinsk Forskning, Tore Nilsons Stiftelse för Medicinsk Forskning, Stiftelsen Lars Hiertas Minne, Svenska Sällskapet 
för Medicinsk Forskning, Svenska Läkaresällskapet, Stiftelsen Professor Gadelius' minnesfond, Stiftelsen Apotekare Hedbergs fond för Medicinsk forskning and the Karolinska Institutet.

\section{REFERENCES}

Abi-Dargham A, Rodenhiser J, Printz D, Zea-Ponce Y, Gil R, Kegeles LS et al (2000). From the cover: increased baseline occupancy of D2 receptors by dopamine in schizophrenia. Proc Natl Acad Sci USA 97: 8104-8109.

Andén NE, Stock G (1973). Effect of clozapine on the turnover of dopamine in the corpus striatum and in the limbic system. $J$ Pharm Pharmacol 25: 346-348.

Arvanov VL, Liang X, Schwartz J, Grossman S, Wang RY (1997). Clozapine and haloperidol modulate $N$-methyl-D-aspartate- and non- $N$-methyl-D-aspartate receptor-mediated neurotransmission in rat prefrontal cortical neurons in vitro. J Pharmacol Exp Ther 283: 226-234.

Bartholini G (1976). Differential effect of neuroleptic drugs on dopamine turnover in the extrapyramidal and limbic system. $J$ Pharm Pharmacol 28: 429-433.

Birch PJ, Grossman CJ, Hayes AG (1988). Kynurenic acid antagonises responses to NMDA via an action at the strychnine-insensitive glycine receptor. Eur J Pharmacol 154: 85-87.

Brunello N, Masotto C, Steardo L, Markstein R, Racagni G (1995). New insights into the biology of schizophrenia through the mechanism of action of clozapine. Neuropsychopharmacology 13: 177-213.

Canton H, Verriele L, Colpaert FC (1990). Binding of typical and atypical antipsychotics to 5-HT1C and 5-HT2 sites: clozapine potently interacts with 5-HT1C sites. Eur J Pharmacol 191: 93-96.

Carlsson A, Waters N, Holm-Waters S, Tedroff J, Nilsson M, Carlsson ML (2001). Interactions between monoamines, glutamate, and GABA in schizophrenia: new evidence. Annu Rev Pharmacol Toxicol 41: 237-260.

Carr DB, Sesack SR (2000). GABA-containing neurons in the rat ventral tegmental area project to the prefrontal cortex. Synapse 38: 114-123.

Chiodo LA, Bunney BS (1983). Typical and atypical neuroleptics: differential effects of chronic administration on the activity of A9 and A10 midbrain dopaminergic neurons. J Neurosci 3: 1607-1619.

Chiodo LA, Bunney BS (1985). Possible mechanisms by which repeated clozapine administration differentially affects the activity of two subpopulations of midbrain dopamine neurons. J Neurosci 5: 2539-2544.

Claghorn J, Honigfeld G, Abuzzahab Sr FS, Wang R, Steinbook R, Tuason $\mathrm{V}$ et al (1987). The risks and benefits of clozapine versus chlorpromazine. J Clin Psychopharmacol 7: 377-384.

Coward DM (1992). General pharmacology of clozapine. $\mathrm{Br}$ J Psychiatry Suppl (17): 5-11.

Coward DM, Imperato A, Urwyler S, White TG (1989). Biochemical and behavioural properties of clozapine. Psychopharmacology 99(Suppl): S6-S12.

Deutch AY, Moghaddam B, Innis RB, Krystal JH, Aghajanian GK, Bunney BS et al (1991). Mechanisms of action of atypical antipsychotic drugs. Implications for novel therapeutic strategies for schizophrenia. Schizophr Res 4: 121-156.

Erhardt S, Blennow K, Nordin C, Skogh E, Lindström LH, Engberg G (2001c). Elevated endogenous kynurenic acid in schizophrenia. Neurosci Lett 313: 96-98.

Erhardt S, Engberg G (2000). Excitation of nigral dopamine neurons by the GABA-A-receptor agonist muscimol is mediated via a release of glutamate. Life Sci 67: 1901-1911.
Erhardt S, Engberg G (2002). Increased phasic activity of dopaminergic neurones in the rat ventral tegmental area following pharmacologically elevated levels of endogenous kynurenic acid. Acta Physiol Scand 175: 45-53.

Erhardt S, Hajos M, Lindberg A, Engberg G (2000). Nicotine induced excitation of locus coeruleus neurons is blocked by elevated levels of endogenous kynurenic acid. Synapse 37: 104-108.

Erhardt S, Mathé JM, Chergui K, Engberg G, Svensson TH (2002b). GABAB-receptors modulate the firing pattern of dopamine neurons in the ventral tegmental area. Naunyn-Schmiedeberg's Arch Pharmacol 365: 173-180.

Erhardt S, Öberg H, Engberg G (2001b). Pharmacologically elevated levels of endogenous kynurenic acid prevent nicotineinduced activation of nigral dopamine neurons. NaunynSchmiedeberg's Arch Pharmacol 363: 21-27.

Erhardt S, Öberg H, Mathé JM, Engberg G (2001a). Pharmacological elevation of endogenous kynurenic acid levels activates nigral dopamine neurons. Amino Acids 20: 353-362.

Erhardt S, Schwieler L, Engberg G (2002a). Excitatory and inhibitory responses of dopamine neurons in the ventral tegmental area to nicotine. Synapse 43: 227-237.

Evins AE, Amico E, Posever TA, Toker R, Goff DC (2002). DCycloserine added to risperidone in patients with primary negative symptoms of schizophrenia. Schizophr Res 56: 19-23.

Farde L, Nordstrom AL, Wiesel FA, Pauli S, Halldin C, Sedvall G (1992). Positron emission tomographic analysis of central D1 and D2 dopamine receptor occupancy in patients treated with classical neuroleptics and clozapine. Relation to extrapyramidal side effects. Arch Gen Psychiatry 49: 538-544.

French ED (1994). Phencyclidine and the midbrain dopamine system: electrophysiology and behavior. Neurotoxicol Teratol 16: 355-362.

French ED, Mura A, Wang T (1993). MK-801, phencyclidine (PCP), and PCP-like drugs increase burst firing in rat A10 dopamine neurons: comparison to competitive NMDA antagonists. Synapse 13: 108-116.

Ganong AH, Cotman CW (1986). Kynurenic acid and quinolinic acid act at $N$-methyl-D-aspartate receptors in the rat hippocampus. J Pharmacol Exp Ther 236: 293-299.

Gerlach J (2002). Improving outcome in schizophrenia: the potential importance of EPS and neuroleptic dysphoria. Ann Clin Psychiatry 14: 47-57.

Gessa GL, Devoto P, Diana M, Flore G, Melis M, Pistis M (2000). Dissociation of haloperidol, clozapine, and olanzapine effects on electrical activity of mesocortical dopamine neurons and dopamine release in the prefrontal cortex. Neuropsychopharmacology 22: 642-649.

Goff DC, Tsai G, Levitt J, Amico E, Manoach D, Schoenfeld DA et al (1999). A placebo-controlled trial of D-cycloserine added to conventional neuroleptics in patients with schizophrenia. Arch Gen Psychiatry 56: 21-27.

Grace AA, Bunney BS (1984a). The control of firing pattern in nigral dopamine neurons: single spike firing. J Neurosci 4: 2866-2876.

Grace AA, Bunney BS (1984b). The control of firing pattern in nigral dopamine neurons: burst firing. J Neurosci 4: 2877-2890.

Heresco-Levy U, Javitt DC, Ermilov M, Mordel C, Silipo G, Lichtenstein M (1999). Efficacy of high-dose glycine in the treatment of enduring negative symptoms of schizophrenia. Arch Gen Psychiatry 56: 29-36.

Heresco-Levy U, Javitt DC, Ermilov M, Silipo G, Shimoni J (1998). Double-blind, placebo-controlled, crossover trial of D-cycloserine adjuvant therapy for treatment-resistant schizophrenia. Int J Neuropsychopharmacol 1: 131-135.

Hilmas C, Pereira EF, Alkondon M, Rassoulpour A, Schwarcz R, Albuquerque EX (2001). The brain metabolite kynurenic acid inhibits alpha7 nicotinic receptor activity and increases non- 
alpha7 nicotinic receptor expression: physiopathological implications. J Neurosci 21: 7463-7473.

Ichikawa J, Dai J, Meltzer HY (2002). 5-HT(1A) and 5-HT(2A) receptors minimally contribute to clozapine-induced acetylcholine release in rat medial prefrontal cortex. Brain Res 939: 34-42.

Ichikawa J, Ishii $\mathrm{H}$, Bonaccorso $\mathrm{S}$, Fowler WL, O'Laughlin IA, Meltzer HY (2001). 5-HT(2A) and $\mathrm{D}(2)$ receptor blockade increases cortical DA release via 5-HT(1A) receptor activation: a possible mechanism of atypical antipsychotic-induced cortical dopamine release. J Neurochem 76: 1521-1531.

Javitt DC, Zylberman I, Zukin SR, Heresco-Levy U, Lindenmayer JP (1994). Amelioration of negative symptoms in schizophrenia by glycine. Am J Psychiatry 151: 1234-1236.

Kalivas PW, Churchill L, Klitenick MA (1993). GABA and enkephalin projection from the nucleus accumbens and ventral pallidum to the ventral tegmental area. Neuroscience 57: $1047-1060$.

Kessler M, Terramani T, Lynch G, Baudry M (1989). A glycine site associated with $\mathrm{N}$-methyl-D-aspartic acid receptors: characterization and identification of a new class of antagonists. $J$ Neurochem 52: 1319-1328.

McGehee DS, Heath MJ, Gelber S, Devay P, Role LW (1995). Nicotine enhancement of fast excitatory synaptic transmission in CNS by presynaptic receptors. Science 269: 1692-1696.

Meltzer HY, Nash JF (1991). Effects of antipsychotic drugs on serotonin receptors. Pharmacol Rev 43: 587-604.

Moghaddam B, Bunney BS (1990). Acute effects of typical and atypical antipsychotic drugs on the release of dopamine from prefrontal cortex, nucleus accumbens, and striatum of the rat: an in vivo microdialysis study. J Neurochem 54: 1755-1760.

Murase S, Mathé JM, Grenhoff J, Svensson TH (1993). Effects of dizocilpine (MK-801) on rat midbrain dopamine cell activity: differential actions of firing pattern related to anatomical localization. J Neural Transm 91: 13-25.

Ossowska K, Pietraszek M, Wardas J, Nowak G, Wolfarth S (1999). Chronic haloperidol and clozapine administration increases the number of cortical NMDA receptors in rats. Naunyn Schmiedeberg's Arch Pharmacol 359: 280-287.

Parsons CG, Danysz W, Quack G, Hartmann S, Lorenz B, Wollenburg C et al (1997). Novel systemically active antagonists of the glycine site of the $N$-methyl-D-aspartate receptor: electrophysiological, biochemical and behavioral characterization. J Pharmacol Exp Ther 283: 1264-1275.

Paxinos G, Watson C (1998). The Rat Brain in Stereotaxic Coordinates, 4th edn Academic Press: New York.

Phillipson OT (1979). Afferent projections to the ventral tegmental area of Tsai and interfascicular nucleus: a horse-radish peroxidase study in the rat. J Comp Neurol 187: 117-144.
Pucak ML, Grace AA (1994). Evidence that systemically administered dopamine antagonists activate dopamine neuron firing primarily by blockade of somatodendritic autoreceptors. J Pharmacol Exp Ther 271: 1181-1192.

Pucak ML, Grace AA (1996). Effects of haloperidol on the activity and membrane physiology of substantia nigra dopamine neurons recorded in vitro. Brain Res 713: 44-52.

Schwarcz R, Rassoulpour A, Wu HQ, Medoff D, Tamminga CA, Roberts RC (2001). Increased cortical kynurenate content in schizophrenia. Biol Psychiatry 50: 521-530.

Sesack SR, Deutch AY, Roth RH, Bunney BS (1989). Topographical organization of the efferent projections of the medial prefrontal cortex in the rat: an anterograde tract-tracing study with Phaseolus vulgaris leucoagglutinin. J Comp Neurol 290: 213-242.

Snyder SH, Greenberg D, Yamumura HI (1974). Antischizophrenic drugs: affinity for muscarinic cholinergic receptor sites in the brain predicts extrapyramidal effects. J Psychiatr Res 11: 91-95.

Speciale C, Wu HQ, Cini M, Marconi M, Varasi M, Schwarcz R (1996). (R,S)-3,4-dichlorobenzoylalanine (FCE 28833A) causes a large and persistent increase in brain kynurenic acid levels in rats. Eur J Pharmacol 315: 263-267.

Squires RF, Saederup E (1998). Clozapine and several other antipsychotic/antidepressant drugs preferentially block the same 'core' fraction of GABA(A) receptors. Neurochem Res 23: 1283-1290.

Tsai G, Yang P, Chung LC, Lange N, Coyle JT (1998). D-serine added to antipsychotics for the treatment of schizophrenia. Biol Psychiatry 44: 1081-1089.

Tung CS, Grenhoff J, Svensson TH (1991). Kynurenate blocks the acute effects of haloperidol on midbrain dopamine neurons recorded in vivo. J Neural Transm Gen Sect 84: 53-64.

Van Tol HH, Bunzow JR, Guan HC, Sunahara RK, Seeman P, Niznik HB et al (1991). Cloning of the gene for a human dopamine D4 receptor with high affinity for the antipsychotic clozapine. Nature 350: 610-614.

Wang RY (1981). Dopaminergic neurons in the rat ventral tegmental area; I. Identification and characterization. Brain Res Rev 3: 123-140.

Werner G, Mountcastle VB (1963). The variability of central neural activity in a sensory system and its implication for the central reflection of sensory events. J Neurophysiol 26: 958-977.

White FJ, Wang RY (1983). Differential effects of classical and atypical antipsychotic drugs on A9 and A10 dopamine neurons. Science 221: 1054-1057.

Wonnacott S, Kaiser S, Mogg A, Soliakov L, Jones IW (2000). Presynaptic nicotinic receptors modulating dopamine release in the rat striatum. Eur J Pharmacol 393: 51-58. 